\title{
Rudimentary third arm arising from the upper back: A rare case
}

\author{
Rupendra Bahadur Adhikari'1, MD, PhD; Amit Thapa ${ }^{1}$, MS, MCh; Chakra Raj Pandey², MS \\ ${ }^{1}$ Department of Neurosurgery, Grande International Hospital, Kathmandu, Nepal \\ ${ }^{2}$ Department of Orthopedics \& Traumatology, Grande International Hospital, Kathmandu, Nepal
}

\section{Corresponding author}

Rupendra B Adhikari, MD, PhD

Email: atom.com@gmail.com

Received 11 Nov 2018

Accepted 1 Dec 2018

\section{Summary}

We report a case of a 2-year-old boy with rudimentary third arm arising from the dorsal spine with associated spinal dysraphism.

The child had presented to us 7 months previously when he underwent full investigations but was not operated owing to poor nutritional status and low hemoglobin. The third arm was present since birth and gradually increased in size as the child grew. The arm was non-functional and was insensitive to sensory stimuli. The child had no neurological deficit pertaining to the condition.

Radiologically, there was myelomeningocele (D5-D8), diastematomyelia (D5-D8), hemi vertebrae at the upper and lower ends of the deformity (D4 \& D9), and partially formed posterior bony elements. The long bone of the arm pseudoarticulated with the ill-formed flat bones of the affected dorsal spine.

The rudimentary limb was disarticulated first. Posterior column of the affected dorsal spine was ill-formed with flat bones intertwining with the dura, hemi cord was present with no bony spur, and lipomeningocele was evident with cord tethering. Detethering of the cord was done followed by repair of the meningocele. There was no neurological deficit post-operatively.

\section{Literature review}

Case reports of accessory limbs have been infrequently described in literature. Authors have ascribed numerous terms, based on their observation, and hypotheses of etiology/ pathogenesis to these accessory/rudimentary limbs - aborted twinning, parasitic twinning, teratoma, tripedus, heterotropic redundancies, "disorganizationlike syndrome", duplication of lower limbs, caudal duplication etc. ${ }^{1-11}$.

Most of the case reports describe accessory limbs originating in the lumbo-sacral region, and having various degrees of spinal dysraphism, and caudal duplication. In comparison, dorsally arising accessory limbs have only been reported thrice in the literature ${ }^{1,2,3}$.

One of the first detailed accounts of an accessory limb attached to the upper back has been reported by Jones et al. in $1889 A D^{1}$. The article describes about a surgery in a 4-month old infant who had an accessory limb with a broad base arising from the base of the neck and upper back. The child was operated upon, and the account of surgery described in the article suggests that there was CSF leak which was controlled during the surgery but the child died after repeated convulsions in the next 56 hours. With no radiological pre-operative assessment to help in those days, the surgeons had presumed that it was safe to disarticulate the limb. Only during the surgery did they realize that the posterior elements of lower cervical and upper dorsal vertebrae were missing or deformed considerably, which was masked by the accessory limb's broad base on clinical examination ${ }^{1}$. Solak et al. have described about a "three-armed infant" and ascribed the condition to heteropagus twinning ${ }^{2}$. A dorsal accessory limb and lumbar meningocele in the same infant is described by Sharma et al., whose article gives further accounts of 2 cases of lumbar accessory limbs ${ }^{3}$. 


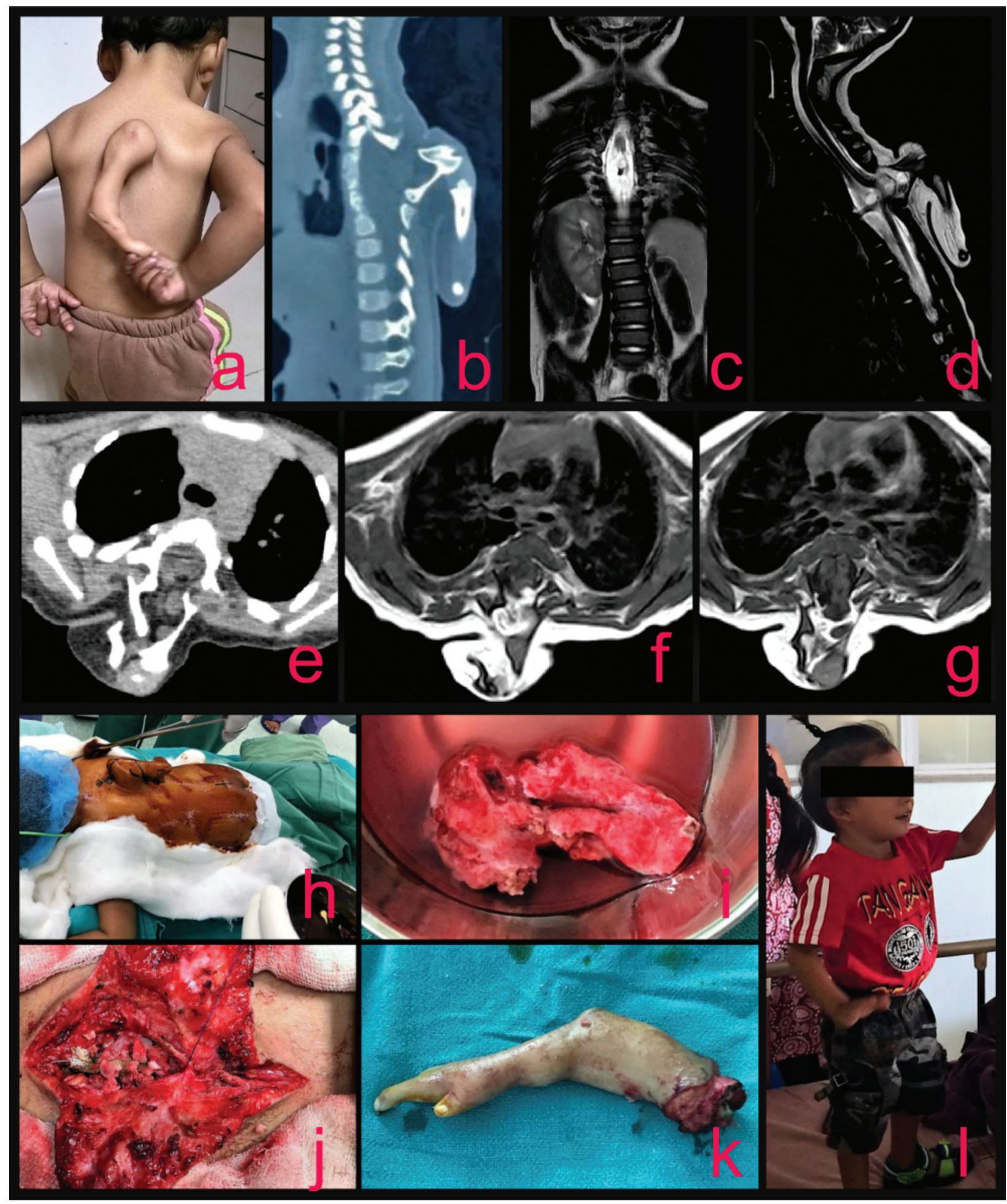

Broadly, two hypotheses regarding the etiology/ pathogenesis to explain the accessory limbs have been mentioned in most of the articles association with neural tube defects, and the concept of parasitic twinning ${ }^{2,4-6,8}$. Based on the in-utero scans, clinic-radiological evidences, and operative findings, one of these hypotheses better explains the anomaly in individual cases. In a few of these cases with additional anomalies ${ }^{5-7}$ these hypotheses do not seem to be mutually exclusive. Distinctly from other reports of infants, Zhang et al. describes about a 17-year old lady with scoliosis, spinia bifida from D8-L5, diplomyelia and tethered cord, and a well-developed breast and an apophysis on the back. 
A better understanding of such condition requires a multi-disciplinary approach from study of embryogenesis, genetic testing, radiology to surgical management.

In our case, the accessory limb was removed, tethered cord released, deficit in posterior elements of the vertebrae repaired. The child had no post-operative neurological deficit, immediately and at interval follow-ups.

\section{Figure Index}

Fig. a: Child reaching out for his 'non-functional' arm

Fig. b;e: Sagittal; Axial CT of the dorsal spine showing hemivertebrae of D4 and D9 vertebral bodies. Bony struts arising from the posterior aspects of D5-D8 vertebral bodies with partial development of posterior elements around them. A large long bone giving the appearance of limb bone is seen pseudoarticulating with these flat bones. Multiple other smaller long bones are seen sequentially pseudoarticulating with this large long bone. There is evidence of soft tissue suggestive of myelomeningocele (correlated with fig. c, d,f,g)

Fig. c;d;f,g: Coronal; Sagittal; Axial MRI showing presence of closed spinal dysraphism and bony spina bifida with myelomeningocele at D5 to D8 vertebral levels. There is associated split cord malformation from D5 below level. Associated adjacent thoracic vertebral anomalies (hemivertebra and unfused vertebra) are also noted. The spinal cord is low lying (ends at the level of L4 vertebra) and is posteriorly tethered (lumbar section not included in fig. d). A bony strut is noted arising from the posterior aspect of D6/ D7 levels. It has two bone segments, larger segment measuring $55 \mathrm{~mm}$ and shorter segment measuring $20 \mathrm{~mm}$ with rudimentary joint between them - likely representing developmental rudimentary accessory third upper limb.

Fig. h: Operative preparation

Fig. i: Excised placode

Fig. j: At the end of spinal reconstruction. Excess skin flap yet to be excised for closure.
Fig. k: Disarticulated limb

Fig. I: A happy child ready to go home after surgery.

\section{References}

1. Jones R, Larkin FC. Removal of accessory limb and meningocele from the back of a child, and its anatomy. BMJ. 1889;310-1.

2. Solak A, Ergün S, Polat i, Şahin N, Genç B. A rare form of heteropagus twinning: Three-armed infant with spinal dysraphism. Case Rep Ped. 2012, Article ID 831649, 4 pages.

3. Sharma L, Singh RB, Bhargava JS, Sharma VK. Accessory limbs with spinal lesions. Pediatr Surg Int. 1991;6(3);227-9.

4. Murphy RF, Cohen BH, Muhlbauer MS, Eubanks JW, Sawyer JR, Moisan A, et al. An accessory limb with lipomyelomeningocele in a male. Pediatr Surg Int. 2013;29(7):749-52.

5. Zhang J, Duan H, Zhang Y, Yi Z, Bao S. Parasitic rachipagus conjoined twins with spina bifida, diplomyelia, scoliosis, tethered cord syndrome, and ventricular septal defect--case report. Neurol Med Chir (Tokyo). 2011;51(10):736-9.

6. Ilkehan H, Coban YK, Guven MA, Ceylaner S. Three new cases of disorganizationlike syndrome: One with accessory extrophia vesicalis J Ped Surg. 2004;39(9):E34.

7. Kota RR, Srirampur S, Kannaiyan L, Irfan GM, Sharab $\mathrm{H}$. Parasitic twinning - Varied presentations. Subba Rao Journal of Dr. NTR University of Health Sciences. 2012;1(3):174-6.

8. Krishna A, Chandna S, Mishra NK, Gupta AK, Upadhyaya P. Accessory limb associated with spina bifida. J Ped Surg. 1989;24(6):604-6.

9. Nanni L, Perrelli L, Velardi F. Accessory lower limb in a newborn with multiple malformations. Eur J Pediatr Surg. 1994;4(1):51-3.

10. Chadha R, Bagga D, Malhotra CJ, Dhar A, Kumar A Accessory limb attached to the back. J Ped Surg. 1993;28(12);1615-7.

11. Wilkes SL, Choi JJ, Rooks VJ. Lumbosacral lipomyelomeningocele with anomalous osseous limb in a 3-month-old female. Radiol Case Rep. 2015;10(1):1051. 